\title{
推进产业发展 助力乡村振兴
}

谭玲惠

中共石柱土家族自治县委党校

DOI:10.32629/as.v2i6.1691

[摘 要] 习近平总书记在党的十九大报告中首次提出实施乡村振兴战略,并为农村发展描绘了 “产业兴旺、生态宜居、乡风文明、治理有效、 生活富裕”的蓝图。某县某乡坚持从自身实际出发, 深度调整产业结构,持续优化产业布局,目前已形成以“中蜂十中药材” 主导的一产, 以“水” 主题的二产, 以 “地质公园十民宿” 支撑三产已初具维形。笔者对此进行了深入调研, 分析了存在的问题, 并提出了几点粗浅的建议, 以期让产业 发展为乡村振兴赋力, 建设美丽富裕的新农村。

[关键词] 产业发展; 乡村振兴; 建议

近年来, 某乡认真落实县委县政府的决策部署, 坚持从自身实际出发, 持续优化产业布局, 努力绘就产业兴、百姓富、生态美的幸福画卷。

\section{1 某乡产业发展有利条件和存在问题}

1. 1 产业发展有利条件。一是生态资源丰富, 动植物种类繁多, 全乡森 林覆盖率高达 $80 \%$, 有水杉、银杉、罗汉松、银杏、桂花、香花等名贵植物, 挂牌名木古树多达 100 多株; 水系发达, 全乡以毛滩河为主的沟河总里程达 到87. 15公里。二是后发优势明显, 这里被誉为重庆的香格里拉, 长期以来 因为交通不便, 没有大规模的开发, 古老传统和丰富资源都得到了较好的 保存, 后发优势将在今后的发展中逐渐显现。三是独有特征显著。其他地 方可能也有山有水有景点, 但这里是独一无二的, 这里有全县保存做好的 传统村落, 是首批国家级村传统村落和市级历史文化名村; 有全国罕见的 喀斯特岩溶地貌一一广寒宫; 有几亿年前地壳运动形成的獐子岩绝壁等独 特景观; 有西南地区富硒含量最高的优质矿泉水资源。

1.2 产业发展存在问题。第一是产业集约化、标准化、规模化程度不 高, 导致产量不高, 质量不齐, 经济效益不明显。某乡4180群中蜂, 其中: 圆 桶中蜂达 1800 群, 圆桶中蜂分散到126户农户中, 每户养殖量少, 只靠天能 产多少蜂蜜算多少蜂蜜, 主动加强管理少。第二是农户认识不足, 观念落 后。广大农户科技文化素质偏低, 仍沿袭着传统的养中蜂, 对深调产业 (皱 皮木瓜) 认可度不高, 对集约化方桶中蜂养殖接受不积极。第三是品牌意识 不强, 没有在打响品牌方面去做文章。虽然某乡着手打造 “木瓜蜜”, 但只 存在蜜源方面解决, 但未对蜂蜜的质量等产品从含量等方面解决少, 导致 产品缺乏具有市场竞争优势。第四是缺乏龙头和专业合作组织带动, 抗风 险能力弱。虽然木本中药材 (皱皮木瓜) 引进了 2 个业主, 中蜂产业引进了 2 个业主建立了 “木瓜+中蜂” 套养有机结合的创新模式, 但相对规还模小, 层次还低, 优质产品少, 市场开拓力差, 拿不出拳头产品, 缺乏市场竞争力, 抗御市场风险的能力差。第五是技术人才支撑不足, 乡农服中心没有专业 中药材人才和中蜂人才, 引进业主虽然具备一定种养技术, 但还不够专业, 县级部门专业技术人员对乡镇产业发展技术指导少。第六是销售渠道严重 不足。某乡年产蜂蜜 10 吨, 目前主要依靠老式熟人销售 2 吨, 电子商务销售 1 吨, 依靠业主或商场其他销售3吨, 还存在大部分滞销。

\section{2 推进某乡产业发展的几点建议}

2. 1 科学制订规划, 引导全乡一二三产业健康有序发展。进一步优化一
二三产业结构和合理规划区域布局, 结合各村实际, 坚持走 “一村一品” 的 产业发展路子。依托各类政策支撑和各村现有一二三产业资源, 科学规划 各类产业有效布置。

2. 2 创新发展模式, 带动产业发展。一是进一步扩大 “中蜂十皱皮木瓜” 套养模式, 大力发展矮杆植物和皱皮木瓜套种等模式, 实现土地立体利用。 二是进一步扩大推广 “示范基地+贫困户或困难党员” 的中蜂养殖带动模 式, 扩大养殖规模, 带动农户发展中蜂。三是结合地质公园旅游资源和传统 村落等优质资源, 探索 “黄水人家+农家乐”三产发展模式, 带动农户发展 乡村旅游, 提高旅游接能力。

2. 3 打造人才队伍, 推动产业发展。一是 “扩宽” 农户产业发展意识。 组织外出培训或内在思想培训, 开拓农户的产业发展思路。二是 “引进” 产业发展人才。依托业主和专业合作社, 引进中药材和中蜂等产业发展高 端人才, 盘活市场人力资源。三是 “培育” 产业发展人才。本土并非没有 人才苗子, 必须要健全人才培养机制和激励机制, 把本土 “土专家” “田秀 才” 培养出来, 培训--任职--再培训, 让这些 “准人才” 在 “练兵” 中成为 人才; 四是 “用活” 产业发展人才。利用行政资源, 积极开展校企合作、 校政合作、政企合作等形式, 加大产业发展的人才支撑。

2.4 突出区域优势, 做强唱响产业品牌。某乡气候湿润, 山青水秀, 全乡 62 平方公里的面积, 还是未被厂矿企业污染的处女地, 在乡境内发展种养 产业, 应该都可以通过国家相关部门的有机食品认证, 这样一来, 不但可以 赢得市场, 更可以赢得巨大的经济和社会效益。

2.5 多途径搭桥, 做通畅销各类产品。一是利用蜂蜜、竹笋等农副产品, 创建生态品牌, 利用乡村旅游搭建平台, 销售农副产品。二是充分利用电子 商务途径, 结合抖音等手段平台, 积极推广农副产品, 扩宽销售途径。三是 利用业主与企业合作, 充分利用订单模式, 推动农副产品销售。

\section{[参考文献]}

[1]秦富.脚踏实地落实乡村振兴战略的目标任务[J].中国乡村发 现,2018(04):151-153.

[2]朱启瑧. 建设美丽乡村 夯实乡村振兴之基[ J]. 农民科技培 训,2018(01):23-25.

[3]申端锋.乡村振兴的关键是三农融合[J].中国农村科技,2018(1):15. 